Bangl. J. Vet. Med. (2010). 8 (2) : 87-92

\title{
ISOLATION AND DETECTION OF NEWCASTLE DISEASE VIRUS FROM FIELD OUTBREAKS IN BROILER AND LAYER CHICKENS BY REVERSE TRANSCRIPTION-POLYMERASE CHAIN REACTION
}

\author{
M. H. Haque ${ }^{1,3}$, M. T. Hossain ${ }^{1}$, M. T. Islam², M. A. Zinnah ${ }^{1}$, M. S. R. Khan ${ }^{1}$ and M. A. Islam ${ }^{*}$ \\ ${ }^{1}$ Department of Microbiology and Hygiene, ${ }^{2}$ Department of Medicine, Faculty of Veterinary Science, \\ Bangladesh Agricultural University, Mymensingh-2202, ${ }^{3}$ Department of Animal Husbandry and Veterinary \\ Science, Rajshahi University, Rajshahi. 'Corresponding author's e-mail: alim_bau@yahoo.co.in
}

\begin{abstract}
The present research work was carried out to isolate and identify Newcastle disease virus (NDV) by using haemagglutination inhibition (HI) test and reverse transcription-polymerase chain reaction (RT-PCR) assay. A total of 160 clinical (blood, tracheal and cloacal swabs) and post-mortem (brain, lung, colon and spleen) samples were collected from chickens of two field outbreaks of Newcastle disease (ND) in 2006, one in a broiler (Cobb-500) farm of Mymensingh district and other one in a layer (Sonali) farm of Gazipur district. All the samples were inoculated onto 10-day-old embryonated chicken eggs through allantoic sac route and in the chicken embryo fibroblasts (CEFs) cell culture. The allantoic fluid (AF) of the dead embryos and the infected culture fluid (ICF) of the CEF were harvested at 48 and 96 hours of post-infection, respectively. The HI and RT-PCR were employed to detect NDV in tissue homogenates of all the clinical and post-mortem samples as well as laboratory samples (AF and ICF). Among the clinical samples, virus isolation rate was found higher from tracheal swab (90\%) compared to those of cloacal swab $(85 \%)$ and serum $(65 \%)$. On the other hand, among the four different types of post-mortem samples, virus isolation rate was found higher in spleen $(100 \%)$ compared to those of lungs $(80 \%)$, colon $(60 \%)$, and brain $(80 \%)$ samples. In CEF cell culture system, the rate of virus isolation from all the aforesaid samples was found $100 \%$ with the exception of serum samples. The isolation rate of NDV was higher in CEF culture system (93.8\%) compared to that of avian embryos (80\%). Among the clinical and post-mortem samples, inoculum of only cloacal swab and colon showed HA and HI activities. The anti-NDV hyperimmune serum revealed complete inhibition of the 4 haemagglutination unit of each isolate of viruses isolated from broiler and layer chickens present in the laboratory samples (AF and ICF). The NDV specific primers used in the direct RT-PCR for genome detection of NDV showed equal sensitivity and specificity with the RNA extracted from the clinical, post-mortem and laboratory samples (AF and ICF) as with the genomic RNA of reference NDV. Higher rate of detection of NDV was recorded with RT-PCR assay than HI test. Therefore, the molecular method (RT-PCR) can be introduced for rapid and confirmatory detection of NDV from any form of outbreak of ND in the field level of Bangladesh.
\end{abstract}

Key words: Newcastle disease virus, isolation, RT-PCR, chickens

\section{INTRODUCTION}

Newcastle disease virus (NDV) which is also called avian paramyxovirus serotype 1 (APMV-1) is a single stranded, enveloped, negative sense RNA virus belonging to the genus Rubulavirus of subfamily Paramyxovirinae and family Paramyxoviridiae (Barbezange and Jestin, 2005; Mayo, 2002). Based on pathogenic and virulence properties, NDV is categorized into three major pathotypic strains i.e. lentogenic, mesogenic and velogenic strains (Beard and Hanson, 1984). NDV causes Newcastle disease (ND), which is an acute highly contagious viral disease of domestic poultry as well as other species of birds regardless of age and sex variation (Alexander, 2003). According to the strain variation of NDV, the rate of morbidity and mortality of poultry in a flock due to ND varies from $90-100 \%$, thereby poultry industry all over the world facing serious economic losses every year (Gohm et al., 2000). ND is also considered as one of the major threats to the poultry raisers of Bangladesh too, because of its high morbidity, mortality and reduced productivity of poultry resulting remarkable economic losses every year since first isolation and identification of the virus from the year 1978 in Bangladesh by Hossain et al. (1978). 


\section{H. Haque and others}

According to Chowdhury et al. (1982), ND alone is responsible for at least 40-60\% of total mortality of poultry population in Bangladesh. Therefore, when there is any outbreak of ND, rapid and confirmatory detection of the viruses are crucial for the adaptation of an effective control of the disease. But, due to lack of availability of rapid and confirmatory diagnostic methods most farmers and even poultry veterinarian of Bangladesh confuse ND with other infectious diseases of poultry. Traditionally, the methods of diagnosis of ND are being practiced at field level of Bangladesh are very much limited within the recording of the clinical signs and post-mortem findings manifested by ND affected birds and some serology-based diagnostic methods like haemagglutination inhibition (HI), virus neutralization (VN) and agar gel immunodiffusion (AGID) tests etc. Although virus isolation followed by identification using most of the serological tests such as enzyme linked immunosorbent assay, fluorescent antibody technique, serum neutralization test, plaque reduction neutralization test and AGIDT are considered as the standard methods for the confirmation of the disease (OIE, 1996) but these are always considered as time consuming and expensive compared to that of genome detection of the virus as a single method. Therefore, genome detection of NDV both from the clinically sick and dead birds is very important for early and rapid confirmatory diagnosis of ND in poultry during outbreak of the disease compared to any other single or combined conventional methods of diagnosis (Jestin and Jestin, 1991; Pedersen et al., 2000). The reverse transcription-polymerase chain reaction (RT-PCR) has established its position top over other confirmatory test methods in the field of diagnosis of ND (Singh et al., 2005; Krzysztof et al., 2006). This paper describes the isolation and molecular detection (RT-PCR) of NDV from the clinical and post-mortem samples of naturally infected broiler and layer chickens.

\section{MATERIALS AND METHODS}

\section{Collection of samples}

A total of 160 clinical (blood, tracheal and cloacal swabs) and post-mortem (lung, brain, colon, spleen) samples, 80 from each outbreak of suspected Newcastle disease (ND) occurred in 2006 in a broiler (Cobb 500) farm in Gazipur and a layer farm of Sonali chickens in Mymensingh. All the samples were transported to the laboratory maintaining $4^{\circ} \mathrm{C}$ on ice and were either processed immediately or stored at $-86^{\circ} \mathrm{C}$.

\section{Reference Newcastle disease virus (NDV)}

NDV strain (Komarov) obtained from the repository of the Department of Microbiology and Hygiene, Bangladesh Agricultural University (BAU), Mymensingh was used as positive control.

\section{Virus isolation}

Virus isolation from clinical and post-mortem samples was performed in 9-11-day-old embryonated chicken eggs and in chick embryo fibroblast (CEF) cells (Uruakpa, 1997). Collection and storage of allantoic fluid (AF) and infected culture fluid (ICF) were done properly.

\section{Haemagglutination (HA) and haemagglutination inhibition (HI) tests}

Tissue homogenates of post-mortem samples, clinical samples, AF and ICF were subjected for slide as well as micro-plate HA test to determine the presence of haemagglutinating virus using $1.5 \%$ and $0.5 \%$ freshly prepared cRBC suspension (Stephen et al., 1975). The HI test using anti-NDV hyperimmune sera raised in chickens was employed with the HA positive samples for identification of NDV.

\section{Extraction of viral RNA}

The genomic viral RNA was extracted from reference NDV, clinical samples, post-mortem samples, ICF and AF by using the QIAamp viral RNA mini kit (QIAGEN, Hilden, Germany) according to the manufacture's protocol and was stored at $-86^{\circ} \mathrm{C}$ until use.

\section{Oligonucleotide primers}

A set of oligonucleotide primers, forward (NDVF) - 5-GCAGCTGCAGGGATTGTGGT-3 (nucleotide position 158-177) and reverse (NDVR) - 5-TCTTTGAGCAGGAGGATGTTG-3́ (nucleotide position 493-513) as designed and used by Nanthakumar et al. (2000) were used for the amplification of 356 bp amplicons corresponding the cleavage activation site of $\mathrm{F}$ gene of NDV. 
Isolation and molecular detection of NDV

\section{Reverse transcription (RT)}

A volume of $4 \mu \mathrm{l}$ of eluted RNA of NDV and $8.3 \mu$ DEPC were taken into individual PCR tube and mixed properly with the help of the minispin. The tubes were then placed in a forty eight wells thermocycler (MJ Mini thermocycler, BIORAD ${ }^{\circledR}$, USA) and heated at $94^{\circ} \mathrm{C}$ for 5 minutes for linearization of coiled RNA followed by snap cooling on ice for 2 minutes. Meanwhile, for the synthesis of cDNA from RNA of NDV, reaction mixture containing $4.0 \mu \mathrm{l}$ 5X RT buffer, $2.0 \mu 110 \mathrm{mM}$ dNTP, $1.0 \mu \mathrm{l}$ prime RNase inhibitor, $0.2 \mu \mathrm{l}$ AMV-RT, and $0.5 \mu \mathrm{l}$ primer (RH 100 pmol) was prepared and kept on ice. After adding this reaction mixture onto the PCR tube containing linearized RNA placed into the thermocycler and followed the thermal profile as $42^{\circ} \mathrm{C}$ for 40 minutes followed by $85^{\circ} \mathrm{C}$ for 5 minutes.

\section{Polymerase chain reaction $(\mathrm{PCR})$}

PCR was carried out in a total volume of $50 \mu \mathrm{l}$ containing $5.0 \mu \mathrm{l} 10 \mathrm{X}$ LA buffer, $2.0 \mu \mathrm{l} 25 \mathrm{mM} \mathrm{MgCl}, 2.0 \mu \mathrm{l}$ $10 \mathrm{mM}$ dNTP, $0.2 \mu \mathrm{l} \mathrm{LA}$-Taq, $0.8 \mu \mathrm{l}$ NDVF primer (100 pmol), $0.8 \mu \mathrm{l}$ NDVR primer (100 pmol), $1.5 \mu \mathrm{l}$ cDNA, and $37.7 \mu \mathrm{l}$ DEPC was added to each tube and mixed with the micropipette and minispin. The tubes were immediately returned to the thermocycler and the cycling programme was resumed at $94^{\circ} \mathrm{C}$ for 2 minutes (initial denaturation) followed by 30 cycles of $94^{\circ} \mathrm{C}$ for 30 seconds (denaturation), $45^{\circ} \mathrm{C}$ for 45 seconds (annealing), $60^{\circ} \mathrm{C}$ for 1 minute (elongation) and final elongation of $60^{\circ} \mathrm{C}$ for 5 minutes.

\section{Agarose gel electrophoresis}

The PCR products were separated in 1.5\% agarose gel in TAE buffer stained with ethidium bromide and compared with molecular mass marker (100 bp DNA marker) and visualized by ultraviolet (UV) transillumination.

\section{RESULTS AND DISCUSSION}

\section{Isolation of NDV}

Results of virus isolation of the present study revealed that among 160 samples including clinical and postmortem samples of both the naturally infected broiler and layer chickens, Newcastle disease virus was isolated from 128 (80\%) samples using the avian embryos and confirmed by HA and HI tests (Table 1, 2).

Among the clinical samples of naturally infected broiler and layer chickens, virus isolation rate was found higher from tracheal swab (90\%) compared to those of cloacal swab $(85 \%)$ and serum $(65 \%)$ (Table 1,2$)$. Higher rate of NDV isolation from tracheal swab in this study might be due to presence of maximum load of the virus in the trachea during the course of infection. As NDV normally spreads through aerosol and ingestion, therefore the virus may have a chance to shed rapidly through trachea. The tracheal swab may be considered as the best source of NDV during sample collection both from the clinical and experimental cases. On the other hand, among the four different types of post-mortem samples, virus isolation rate was found higher in spleen (100\%) compared to those of lungs $(80 \%)$, colon $(60 \%)$, and brain $(80 \%)$ samples. As spleen is a lymphoid organ and it filters the blood, during viremic condition there is a chance of infiltration of NDV from the blood to the spleen. For that virus concentration and rate of infection may be higher in spleen and it may be the best source of virus compared to other organs collected during post-mortem sampling of both the natural and experimental cases. The findings of NDV isolation of the present study support the findings of Majid and Peter (2006), Krzysztof et al. (2006) and Singh et al. (2005). Among them, Majid and Peter (2006) isolated NDV from blood at 4 days after infection and other scientists isolated NDV at almost similar rate as of the present findings from tracheal swab, cloacal swab, spleen, lung, and colon and brain from the natural cases of ND.

NDVs were isolated from $150(93.8 \%)$ out of a total 160 collected samples propagating in CEF cell culture system and confirmed by HA and HI tests in this study (Table 1,2). The rate of virus isolation in CEF cell culture system from all the aforesaid of the clinical and post-mortem samples was found $100 \%$ with the exception of serum samples. As serum samples were collected at day 1, day 2 and day 3 of post-infection and virus isolation was possible from the blood samples collected at day 1 and day 2 only. 


\section{H. Haque and others}

None of the serum samples collected at day 3 post-infection was found positive for virus isolation both in avian embryo and CEF cell culture system. The failure of virus isolation from the blood samples at day 3 post-infection might be due to the lodgment of the virus in different tissues of the infected birds at day 3 of post infection. The findings of NDV isolation using CEF cell culture system has close agreement with the findings of Mohan et al. (2005) and Takehara et al. (1987). In their study, the isolation rate of NDV was higher in CEF culture system compared to that of avian embryo. It was found that virus isolation rate both from the clinical and post-mortem samples except serum of day 3 post-infection was $100 \%$ in cell culture compared to that of the avian embryo as the isolation rate varies (Table 1,2). The reduced rate of virus isolation in avian embryo may be due to the presence of maternal antibody.

Table 1. Newcastle disease virus isolated from the clinical and post-mortem samples of naturally infected broiler chickens

\begin{tabular}{lllll}
\hline Type of samples & & $\begin{array}{l}\text { No. of samples } \\
\text { inoculated }\end{array}$ & \multicolumn{2}{l}{ No. of samples positive for virus isolation (\%) } \\
\cline { 3 - 5 } Clinical samples & Tracheal swab & 20 & $18(90)$ & CEF \\
& Cloacal swab & 20 & $17(85)$ & $20(100)$ \\
& Serum & $15^{\mathrm{a}} / 20^{\mathrm{b}}$ & $13^{\mathrm{a}}(86.7) / 13^{\mathrm{b}}(65)$ & $15^{\mathrm{a}}(100)$ \\
\multirow{2}{*}{$\begin{array}{l}\text { Post-mortem } \\
\text { samples }\end{array}$} & Spleen & 5 & $5(100)$ & $5\left(15^{\mathrm{b}}(75)\right.$ \\
& Lung & 5 & $4(80)$ & $5(100)$ \\
& Brain & 5 & $4(80)$ & $5(100)$ \\
& Colon & 5 & $3(60)$ & $5(100)$ \\
\hline
\end{tabular}

${ }^{\mathrm{a}}$ Serum of day 1 and day 2 , ${ }^{\mathrm{b}}$ Pool serum of day 1 , day 2 and day $3, \mathrm{CEF}=$ Chicken embryo fibroblasts.

Table 2. Newcastle disease virus isolated from the clinical and post-mortem samples of naturally infected layer chickens

\begin{tabular}{lllll}
\hline Type of samples & & $\begin{array}{l}\text { No. of samples } \\
\text { inoculated }\end{array}$ & \multicolumn{2}{l}{ No. of samples positive for virus isolation (\%) } \\
\cline { 5 - 5 } \cline { 4 - 5 } Clinical samples & Tracheal swab & 20 & $18(90)$ & CEF \\
& Cloacal swab & 20 & $17(85)$ & $20(100)$ \\
\multirow{2}{*}{$\begin{array}{l}\text { Post-mortem } \\
\text { samples }\end{array}$} & Serum & $15^{\mathrm{a}} / 20^{\mathrm{b}}$ & $13^{\mathrm{a}}(86.7) / 13^{\mathrm{b}}(65)$ & $15^{\mathrm{a}}(100) / 15^{\mathrm{b}}(75)$ \\
& Spleen & 5 & $5(100)$ & $5(100)$ \\
& Lung & 5 & $4(80)$ & $5(100)$ \\
& Brain & 5 & $4(80)$ & $5(100)$ \\
& Colon & 5 & $3(60)$ & $5(100)$ \\
\hline
\end{tabular}

${ }^{\mathrm{a}}$ Serum of day 1 and day $2,{ }^{\mathrm{b}}$ Pool serum of day 1 , day 2 and day $3, \mathrm{CEF}=$ Chicken embryo fibroblasts.

\section{Detection of NDV}

Among the clinical and post-mortem samples, inoculum of only cloacal swab and colon showed HA and HI activities (Table 3). This might be due to the presence of high concentration of free NDV in both types of samples during early and advanced stage of the disease. The anti-NDV hyperimmune serum revealed complete inhibition of the 4 haemagglutination unit of each isolate of viruses isolated from broiler and layer chickens present in the laboratory samples (AF and ICF). Results of HI test of the present study directly support the findings of Manin et al. (2002), Peroulis and O'Riley (2004) and Seal et al. (2005) who confirmed NDV by HI test. 
Table 3. Detection of Newcastle disease virus from the clinical and post-mortem samples of naturally infected broiler and layer chickens

\begin{tabular}{|c|c|c|c|c|c|c|}
\hline \multirow{2}{*}{ Type of samples } & & \multirow{2}{*}{$\begin{array}{l}\text { Time of sample collection } \\
\text { (Days post-infection) }\end{array}$} & \multicolumn{3}{|c|}{ HA and $\mathrm{HI}$ tests } & \multirow[t]{2}{*}{ RT-PCR } \\
\hline & & & $\begin{array}{l}\text { Direct tissue } \\
\text { suspension }\end{array}$ & $\mathrm{AF}$ & $\mathrm{ICF}$ & \\
\hline \multirow[t]{9}{*}{ Clinical samples } & \multirow[t]{3}{*}{ Tracheal swab } & Day 1 & - & + & + & + \\
\hline & & Day 2 & - & + & + & + \\
\hline & & Day 3 & - & + & + & + \\
\hline & \multirow[t]{3}{*}{ Cloacal swab } & Day 1 & - & + & + & + \\
\hline & & Day 2 & + & + & + & + \\
\hline & & Day 3 & - & + & + & + \\
\hline & \multirow[t]{3}{*}{ Serum } & Day 1 & - & + & + & + \\
\hline & & Day 2 & - & + & + & + \\
\hline & & Day 3 & - & - & - & - \\
\hline \multirow[t]{4}{*}{ Post-mortem samples } & Spleen & \multirow{4}{*}{$\begin{array}{l}\text { All the PM samples were } \\
\text { collected immediately after } \\
\text { death of the birds within } 3-4 \\
\text { days of post-infection }\end{array}$} & - & + & + & + \\
\hline & Lung & & - & + & + & + \\
\hline & Colon & & + & + & + & + \\
\hline & Brain & & - & + & + & + \\
\hline
\end{tabular}

$\mathrm{AF}=$ Allantoic fluid, $\mathrm{ICF}=$ Infected culture fluid, $\mathrm{RT}-\mathrm{PCR}=$ Reverse transcriptase polymerase chain reaction, $+=$ Positive,$-=$ Negative.

The genomes of NDV were detected by direct RT-PCR using NDV specific primers isolated from all the clinical and post-mortem samples of the infected broiler and layer chickens. The NDV specific primers used in the direct RT-PCR for genome detection of NDV showed equal sensitivity and specificity with the RNA extracted from the clinical, post-mortem and laboratory samples (AF and ICF) as with the genomic RNA of standard NDV (Fig. 1 and Table 3). Results of the molecular detection of the present study highly agree with the findings of Jestin and Jestin (1991), Creelan et al. (2002) and Wambura et al. (2006).

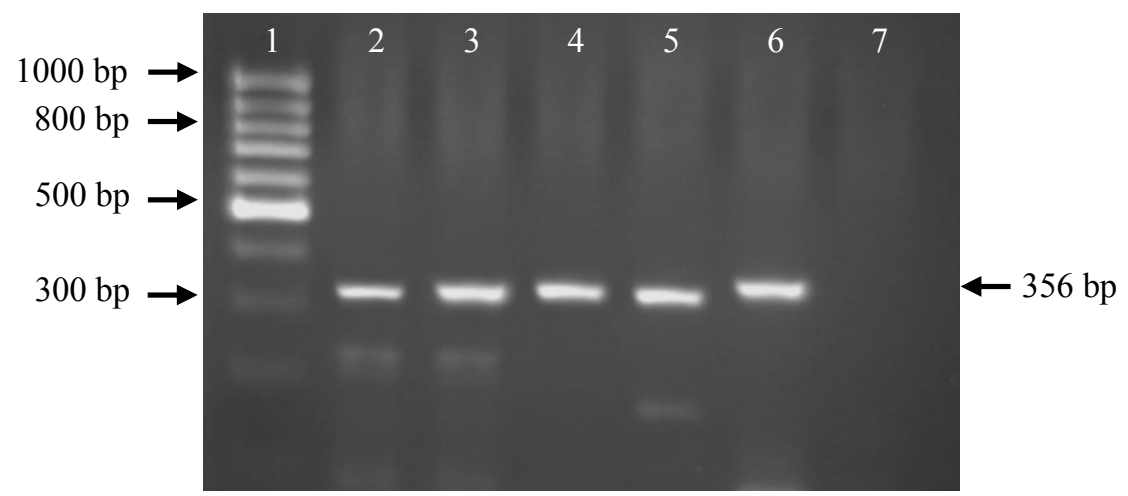

Fig. 1. RT-PCR products (356 bp) amplified from field samples and a reference strain of NDV visualized following electrophoresis on ethidium bromide stained $1.5 \%$ agarose gel. Lane 1 = DNA marker (100bp), Lane 2 $=$ Positive control (Komarov strain of NDV), Lane 3-4 = Clinical samples (tracheal and cloacal swabs), Lane $5=$ Post-mortem sample (spleen), Lane $6=$ Laboratory sample (allantoic fluid), Lane $7=$ Negative control (IBDV). 


\section{H. Haque and others}

As Newcastle disease is one of the most important infectious as well as viral disease of poultry and responsible for remarkable economic losses in poultry sector every year, rapid detection and identification of the viruses are crucial for the adaptation of an effective control of the disease. Therefore, the molecular method (RT-PCR) can be introduced for rapid and confirmatory detection of NDV from any form of outbreak of ND in the context of Bangladesh.

\section{REFERENCES}

1. Alexander DJ (2003). Newcastle disease, other avian paramyxoviruses, and pneumovirus infections. In: Saif Y, Barnes JH, Glisson JR, Fadly AM, McDouglad LR and Swayne DE (Eds.), Diseases of Poultry. $11^{\text {th }}$ edn., Iowa State University Press, Ames, USA. pp. 63-99.

2. Barbezange C and Jestin V (2005). Molecular study of the quasispecies evolution of a typical pigeon paramyxovirus type 1 after serial passages in pigeons by contact. Avian Pathology $34: 111-122$.

3. Beard CW and Hanson RP (1984). Newcastle Disease. In: MS Hofstad, HJ Barnes, BW Calnek, WM Reid and HW Yoder (Eds.), Diseases of Poultry. $8^{\text {th }}$ edn., Iowa State University Press, Ames, USA. pp. 452-470.

4. Chowdhury TIMFR, Sarker AJ, Amin MM and Hossain WIMA (1982). Studies on Newcastle disease in Bangladesh. A Research Report, Sec 2. The role of residual maternal antibody on immune response and selection of an optimum age for primary vaccination of chicks. pp. 12-22.

5. Creelan JL, Graham DA and McCullough SJ (2002). Detection and differentiation of pathogenicity of avian paramyxovirus serotype 1 from field cases using one-step reverse transcriptase-polymerase chain reaction. Avian Pathology 31 : 493-499.

6. Gohm DS, Thur B and Hofmann MA (2000). Detection of Newcastle disease virus in organs and faeces of experimentally infected chickens using RT-PCR. Avian Pathology 29 : 143-152.

7. Hossain WIMA, Chowdhury TIMF, Amin MM and Rahman MM (1978). Pathogenic characteristics of two selected isolates of Newcastle disease virus from Bangladesh. Bangladesh Veterinary Journal $12: 35-42$.

8. Jestin V and Jestin A (1991). Detection of Newcastle disease virus RNA in infected allantoic fluids by in vitro enzymatic amplification (PCR). Archives of Virology $118: 151-161$.

9. Krzysztof S, Zenon M and Katarzyna D (2006). Detection of Newcastle disease virus in infected chicken embryos and chicken tissues by RT-PCR. The Bulletin of the Veterinary Institute in Pulawy $50: 3-7$.

10. Majid B and Peter S (2006). Early events following oral administration of Newcastle disease virus strain V4. International Journal of Poultry Science 43 : 408-414.

11. Manin TB, Shcherbakova LO, Bochkov IA, El'nikov VV, Pchelkina IP, Starov SK and Drygin VV (2002). Characteristics of field isolates of Newcastle disease virus isolated in the course of outbreaks in the poultry plant in the Leningrad region in 2000: Voprosy Virusologii 47 : 41-43.

12. Mayo MA (2002). A summary of taxonomic changes recently approved by ICTV. Archives of Virology 147: 1655-1663.

13. Mohan MC, Dey S and Kumanan K (2005). Molecular changes of the fusion protein gene of chicken embryo fibroblastadapted velogenic Newcastle disease virus: effect on its pathogenicity. Avian Diseases 49:56-62.

14. Nanthakumar T, Kataria RS, Tiwari AK, Butchaiah G and Kataria JM (2000). Pathotyping of Newcastle disease viruses by RT-PCR and restriction enzyme analysis. Veterinary Research Communications 24 : 275-286.

15. OIE (1996). Newcastle disease. In: OIE Manual of Standards for Diagnostic Tests and Vaccines, Paris. pp. 161-169.

16. Pedersen JC, Reynolds DL and Ali A (2000). The sensitivity and specificity of a RT-PCR assay for the avian pneumovirus (Colorado strain). Avian Diseases 44 : 681-685.

17. Peroulis I and O'Riley K (2004). Detection of avian paramyxoviruses and influenza viruses amongst wild bird populations in Victoria. Australian Veterinary Journal 82 : 79-82.

18. Seal BS, Wise MG, Pedersen JC, Senne DA, Alvarez R, Scott MS, King DJ, Yu Q and Kapczynski DR (2005). Genomic sequences of low-virulence avian paramyxovirus-1 (Newcastle disease virus) isolates obtained from live-bird markets in North America not related to commonly utilized commercial vaccine strains. Veterinary Microbiology 106 : 7-16.

19. Singh K, Jindal N, Gupta SL, Gupta AK and Mittal D (2005). Detection of Newcastle disease virus genome from the field outbreaks in poultry by reverse transcription - polymerase chain reaction. International Journal of Poultry Science 4 : 472475.

20. Stephen W, Rao SBV and Agarwal KK (1975). Standard methods for the examination of avian pathogens. Federal Register $42: 434$.

21. Takehara K, Shinomiya T, Kobayashi H, Azumi Y, Yamugani T and Yoshimura M (1987). Characterization of Newcastle disease viruses isolated from field cases in Japan. Avian Diseases 31 : 125-129.

22. Uruakpa UA (1997). Preservation of Newcastle disease vaccine at room temperature. M.V.Sc thesis, University of Queensland, Australia.

23. Wambura P, Meers J and Spradbrow P (2006). Determination of organ tropism of Newcastle disease virus (strain I-2) by virus isolation and reverse transcription-polymerase chain reaction. Veterinary Research Communications 30 : 697-706. 